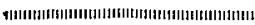

研 究

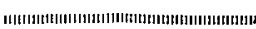

\title{
Ti $(\mathrm{C}, \mathrm{N})-\mathrm{Mo}$ 焼 結 体 の 性 質*
}

\author{
鈴 木 寿**，松 原 秀 彰**
}

\author{
Hisashi Suzuki, and Hideaki Matsubara: Properties of Ti(C, N)-Mo Sintered \\ Compacts.
}

The microstructures, mechanical properties at room temperature of $\mathrm{TiC}_{0.7} \mathrm{~N}_{0.3^{-}}$and $\mathrm{TiC}_{0.5} \mathrm{~N}_{0.5^{-}}$ (5 40) vol\% Mo alloys vacuum-sintered at $1973 \mathrm{~K}$ were mainly studied.

It was found that microstructures of $\mathrm{TiC}_{0.7} \mathrm{~N}_{0.3^{-}}$and $\mathrm{TiC}_{0.5} \mathrm{~N}_{0.5}-\mathrm{Mo}$ alloys consisted of carbonitride and Mo phases, when Mo content exceeded about 20 and 10 vol\%, respectively, and the structure became finer with increasing nitrogen and $\mathrm{Mo}$ contents in the alloys. In the alloys sintered in nitrogen, $\mathrm{Mo}_{2} \mathrm{C}$ phase was apt to form and the amount depended on nitrogen pressures as well as the nitrogen content of alloys. The transverse-rupture strength and hardness of vacuum-sintered alloys were higher in the alloy with lower nitrogen content, and the former increased and the latter decreased with increasing Mo content, respectively.

(Received May 5, 1983)

\section{I 緒言}

著者らはてれまで $\beta(\mathrm{N})^{11}, \beta(\mathrm{N})-\mathrm{WC}^{22}, \mathrm{Ti}(\mathrm{C}, \mathrm{N})-$ $\mathrm{Mo}_{2} \mathrm{C}^{3)}$ などの炭窒化物系焼結体 $(\beta(\mathrm{N})$ は $\mathrm{WC}-\mathrm{TiC}-$ TiN の固溶体）汇関する研究を行ってきており，奏際 にも注目すべき多くの知見をえてきているが，ててでは 耐酸化性の優れる $\mathrm{Ti}(\mathrm{C}, \mathrm{N})^{4)}$ 亿着目し，乙れを高融点 金属 $(\mathrm{Mo})$ を用いて鈤結・結合した合金を引続き検討す ることにした．とこで Mo 老結合相として用いたのは， $\mathrm{Ti}(\mathrm{C}, \mathrm{N})$ 単体の場合より屯勤性加優れ，かつ高温強度 あ隻机る材料がえられるのではないかと思われたからで あるが，むちろんのこと， Ti (C, N )-Mo 合金汇関する報 文はまだ見当らない。よって本研究では上記合金の組織, 室温機械的性質などを烧結条件, 晊素 $(\mathrm{N})$ 量, Mo 量な どとの関係で検討し，本合金北関する基礎的知見をえよ うとした，比較のために， Ti $(\mathrm{C}, \mathrm{N})-\mathrm{W}$ および TiC-Mo (W) 合金について屯簢単な検討を加えた。

\section{III試料調製および実験方法}

市販の $\mathrm{TiC}_{0.7} \mathrm{~N}_{0.3}(13.82 \% \mathrm{C}, 6.20 \% \mathrm{~N}), \mathrm{TiC}_{0.5} \mathrm{~N}_{0.5}$ $(9.86 \% \mathrm{C}, 10.42 \% \mathrm{~N}), \mathrm{Mo}$ 粉末（粒度はいずれも 1.0 $1.5 \mu \mathrm{m})$ を用い, ボール・ミル, 乾燥, 成形をへて, 真 空中 (6.7Pa)，(1873 1973) K ×3.6ks O焼結在行い, $\mathrm{TiC}_{0.7} \mathrm{~N}_{0.3}-\mathrm{Mo}, \mathrm{TiC}_{0.5} \mathrm{~N}_{0.5}-\mathrm{Mo}_{0}$ 合金を作った。なお，必 要により $\mathrm{N}_{2}$ 気流中（压力は $0.1 \sim 10 \mathrm{kPa}$ ）で焼結した 合金屯作った.ここで Mo 含有量は 5 40vol\% の間で 変化させた。また一部の試料については $200 \mathrm{MPa} の \mathrm{Ar}$
中， $2073 \mathrm{~K} \times 3.6 \mathrm{ks}$ の HIP 処理を施した．以上の試料 の他, 比較のために $\mathrm{TiC}_{0.7} \mathrm{~N}_{0.3}\left(\mathrm{TiC}_{0.5} \mathrm{~N}_{0.5}\right)-\mathrm{W}, \mathrm{TiC}-\mathrm{Mo}_{\mathrm{O}}$ (W) 合金なども同様にして調製した。

Ti(C, N )をMoで焼結・結合した各試料について, ま ず光顕または SEM による組織観察を行い，狫結性や 組織などに及ぼす焼結条件，N 量，Mo 量などの影響を 調べた。この時出現相の同定にはX線回折と EPMA 分 析を併用し，合金中の $\mathrm{N}$ 量の定量には傝場製の酸素・窒 素分析装監（EMGA-1200）を用いた。室温抗折力, 硬 さの測定は真空焼結した Ti $(\mathrm{C}, N)-M_{0}$ 合金について行 い，機械的性質上組織との関係を追求した． Ti $(\mathrm{C}, \mathrm{N})$ $\mathrm{W}, \mathrm{TiC}-\mathrm{Mo}(\mathrm{W})$ 合金についても検討したが，狫結性， 組織の点で上記の合金に及ばないことが分かったので， これら合金については亡くに機械的性質などは調べなか った。

\section{III 実 験 結 果}

$\mathrm{N}$ 含むこの種の合金を焼結すると，合金中のN晊は 一般に焼結条件によって変動するので，以下の記述は便 宜上配合組成をむって示すととにする，そてで，以下主 として $\mathrm{Ti}(\mathrm{C}, \mathrm{N})-\mathrm{Mo}$ 合金について述べることにする が，乙の場合は $\mathrm{Ti}(\mathrm{C}, \mathrm{N})-\mathrm{Mo}_{2} \mathrm{C}$ 㸁結体の場合 ${ }^{3)}$ 之同様, 1873K以下の焼結温度では㝓囲気によらず維密化が不十 分であった. Photo. 1 には 1973K で真空焼結した

* 昭和58年 4 月日本金属学会東京大会飞て一部発表，昭和58 年 5 月 9 日受理

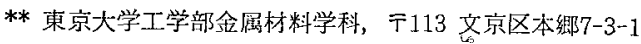




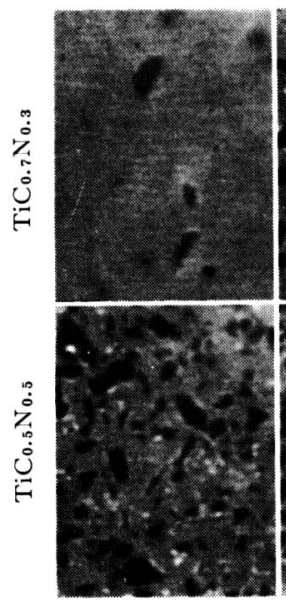

$5 \% \mathrm{Mo}$

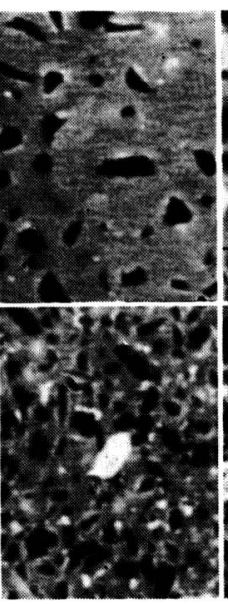

$10 \% \mathrm{Mo}$

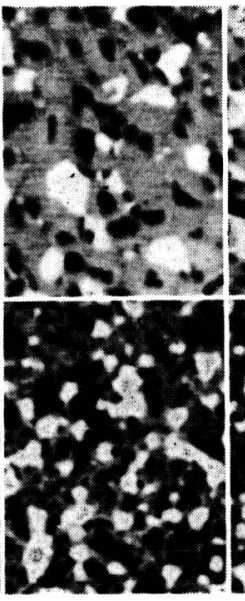

$20 \% \mathrm{Mo}$

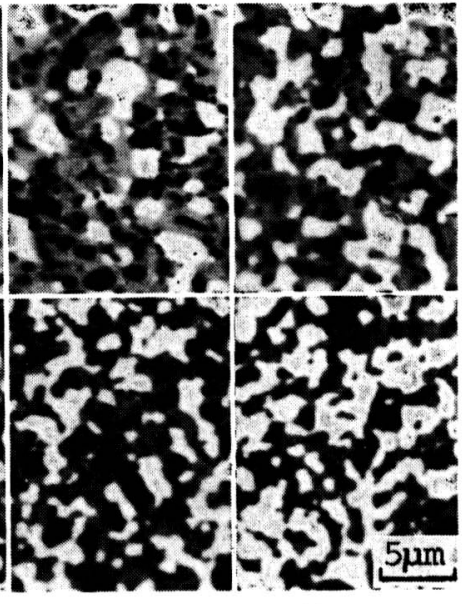

$40 \% \mathrm{Mo}$

Photo. 1 Microstructures of $\mathrm{TiC}_{0.7} \mathrm{~N}_{0.3}\left(\mathrm{TiC}_{0.5} \mathrm{~N}_{0.5}\right)-(5 \sim 40)$ vol $\%$ Mo alloys vacuum-sintered at $1973 \mathrm{~K}$ for $3.6 \mathrm{ks}$.

$\mathrm{TiC}_{0.7} \mathrm{~N}_{0.3}-(5 \sim 40) \% \mathrm{Mo}$ および $\mathrm{TiC}_{0.5} \mathrm{~N}_{0.5}-(5 \sim 40) \%$ Mo 合金の組織を示した．これよりいずれの合金の組織 にあ Mo 量が少ない場合には黒色および灰色の相, Mo 量が多い場合にはこ扎らの相に加えて白色の相が生じる ことが分かる.X線回折および EPMA 分析の結果, 黒 色，灰色および白色の相はそれぞれ $\operatorname{Ti}(\mathrm{C}, \mathrm{N})$ 相， $\mathrm{Ti}(\mathrm{C}$, N)-Mo 固溶体相および金属 Mo 相であるととが分かっ た.即ちこの場合の組織は, $\mathrm{Ti}(\mathrm{C}, \mathrm{N})$ の周りに周辺組織() (Ti(C, N)-Mo の固溶体相, SS) を有する炭窒化物相の 他に, Mo が多い場合には Mo 相を生じることが明らか となる。そこで SS の厚さに注目すると，それは高 Mo となるほど，また高 $\mathrm{N}$ 合金ほど薄くなり，乙のような合 金ほど炭窒化物が微粒化している．また Mo 相につい ては, $\mathrm{TiC}_{0.7} \mathrm{~N}_{0.3}-\mathrm{Mo}$ 合金では約 $20 \%$ 以上で, $\mathrm{TiC}_{0.5} \mathrm{~N}_{0.5}-$ Mo 合金では約10\%以上で生じるので, 同一 Mo 量の下 では高N合金の方が多量となることが注目される.

以上は真空燒結陚料の場合であったが, 真空焼結を行 うと炭窒化物は脱窒し, 合金中の $\mathrm{N}$ 量が減少してしまう (後述).そこで次に脱窒を抑えるために $\mathrm{N}_{\mathbf{2}}$ 中で焼結 した. Photo. 2 は $\mathrm{TiC}_{0.7} \mathrm{~N}_{0.3}\left(\mathrm{TiC}_{0.5} \mathrm{~N}_{0.5}\right)-30 \% \mathrm{Mo}$ 合金 についての組織例である.ここで焼結条件は $0.7 \mathrm{kPaN}_{2}$, $1973 \mathrm{~K} \times 3.6 \mathrm{ks}$ とした．これによると，いずれの合金に も組織中に真空焼結の場合 (Photo. 1) と同様, 白色の相 が観察される. しかしその量は真空焼結の場合よりもや や増加している. Fig. 1 亿は $\mathrm{TiC}_{0.7} \mathrm{~N}_{0.3}-30 \%$ Mo 合金の X線回折図を焼結雾囲気との関係で示した。真空焼結の 場合は $\mathrm{Ti}(\mathrm{C}, \mathrm{N})$ 以外の相としては Mo のみが検出され たが, $\mathrm{N}_{2}$ 中焼結を行うと $\mathrm{Mo}$ と共に $\mathrm{Mo}_{2} \mathrm{C}$ が生じ, $\mathrm{N}_{2}$ 圧力 $\left(P_{N_{2}}\right)$ が $10 \mathrm{kPa}$ 程度と大きくなると $\mathrm{Mo}_{2} \mathrm{C}$ のみを 生じる.このような傾向は $\mathrm{TiC}_{0.5} \mathrm{~N}_{0.5}-30 \% \mathrm{Mo}$ 合金で

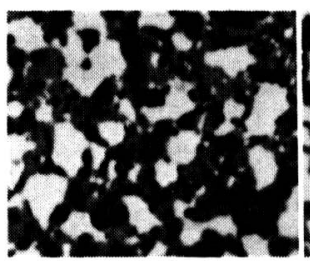

$\mathrm{TiC}_{0.7} \mathrm{~N}_{0.3}$

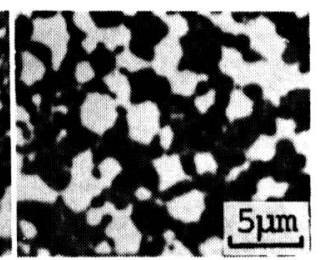

$\mathrm{TiC}_{0.5} \mathrm{~N}_{0.5}$
Photo. 2 Microstructures of $\mathrm{TiC}_{0.7} \mathrm{~N}_{0.3}\left(\mathrm{TiC}_{0.5} \mathrm{~N}_{0.5}\right)-30 \mathrm{vol}$ $\%$ Mo alloys sintered in $\mathrm{N}_{2}$ of $0.7 \mathrm{kPa}$ at $1973 \mathrm{~K}$ for $3.6 \mathrm{ks}$.

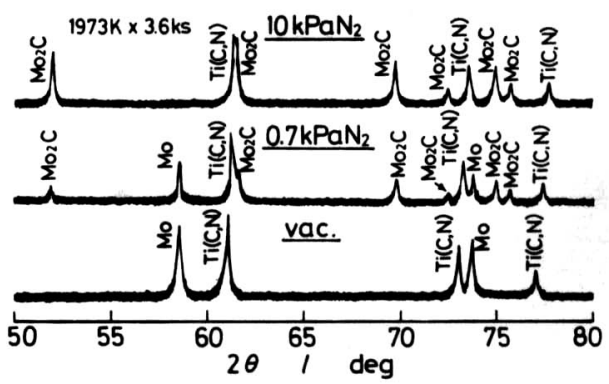

Fig. 1 X-ray diffraction patterns of $\mathrm{TiC}_{0 .} \mathrm{N}_{0.3}-30 \mathrm{vol} \% \mathrm{Mo}$ alloy in relation to sintering atmospheres. $\mathrm{Cu} \mathrm{K}_{\boldsymbol{\alpha}}$, used.

あ同様であった．即ち Photo. 2 でみられた白色相は Mo と $\mathrm{Mo}_{2} \mathrm{C}$ からなるととが分かる.なお図は略した が, $5 \%$ Moでは両合金とも焼結雾囲気によらず Mo あ $\mathrm{Mo}_{2} \mathrm{C}$ も検出されなかった。これは $\mathrm{Mo}, \mathrm{Mo}_{2} \mathrm{C}$ が $\mathrm{SS}$ 形成に消費されてしまうためとしてよい.

Fig. 2 には, $\mathrm{TiC}_{0.7} \mathrm{~N}_{0.3}\left(\mathrm{TiC}_{0.5} \mathrm{~N}_{0.5}\right)-(5,30) \% \mathrm{Mo}$ 合金 について，合金中 $\mathrm{N}$ 量と焼結雾囲気との関係を示す。こ こで合金中 $\mathrm{N}$ 量は $\mathrm{Ti}(\mathrm{C}, \mathrm{N})$ 中に換算した值で示した. な押図中の点線は原料 $\mathrm{Ti}(\mathrm{C}, \mathrm{N})$ 粉末の $\mathrm{N}$ 量を示す. 


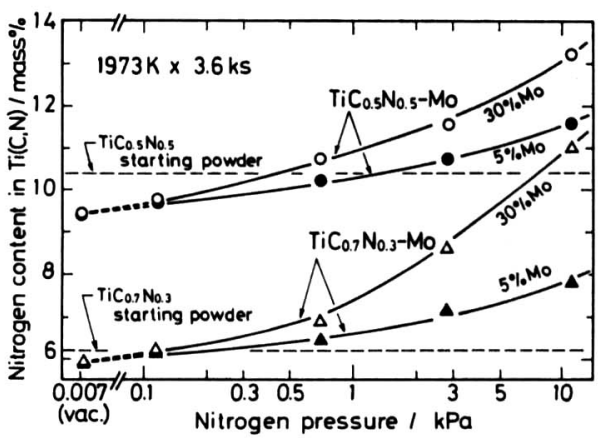

Fig. 2 Nitrogen contents of $\mathrm{TiC}_{0.7} \mathrm{~N}_{0.3}\left(\mathrm{TiC}_{0.5} \mathrm{~N}_{0.5}\right)-(5,30)$ $\mathrm{vol} \%$ Mo alloys in relation to sintering atmospheres.

これより, いずれの合金も真空焼結では脱窒し, $P_{N_{2}}$ と 共に加窒されることが明らかであるが, 脱窒量は高N合 金ほど多く，加窒量は低N合金ほど多くなる．乙れは当 然の結果と考えるか，加窒量が両合金とも高 Mo 合金 ほど多くなる理由はよく分からない，

次に，比較のために $\mathrm{Ti}(\mathrm{C}, \mathrm{N})-\mathrm{W}$ 合金の組織を調べ た. Photo. 3 には Photo. 1 上同じ条件で真空焼結した $\mathrm{TiC}_{0.7} \mathrm{~N}_{0.3}\left(\mathrm{TiC}_{0.5} \mathrm{~N}_{0.5}\right)-30 \% \mathrm{~W}$ 合金の組織例を示した. 白色相はこの場合金属W相であるが， $\mathrm{Ti}(\mathrm{C}, \mathrm{N})-30 \% \mathrm{Mo}$ 合金 (Photo. 1) に比べて炭窒化物相およびW相が共に粗 粒化している. Photo. 4 にはNを含まない TiC-30\%Mo (W) 合金を真空焼結した時の組織を参考のために掲げた が, 両合金と屯 $\mathrm{Ti}(\mathrm{C}, \mathrm{N})-30 \% \mathrm{Mo}(\mathrm{W})$ 合金 (Photo. 1, 3) に比べると著しい粗粒組織となり，しかもポアを生じや すいととが分かる. $\mathrm{Ti}(\mathrm{C}, \mathrm{N})-\mathrm{W}$ および $\mathrm{TiC}-\mathrm{Mo}(\mathrm{W})$ 合 金が $\mathrm{Ti}(\mathrm{C}, \mathrm{N})-\mathrm{Mo}$ 合金に比べて 粗粒化の傾向にある ことは, $\mathrm{N}_{2}$ 中焼結の場合あ同様であった。なお, $\mathrm{Ti}(\mathrm{C}$, $\mathrm{N})-\mathrm{W}, \mathrm{TiC}-\mathrm{Mo}(\mathrm{W})$ 合金を $\mathrm{N}_{2}$ 中で焼結すると結合相の

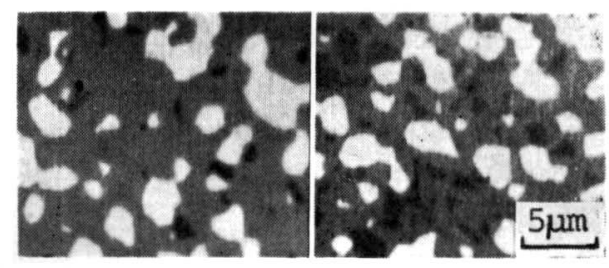

$\mathrm{TiC}_{0.7} \mathrm{~N}_{0.3}$

$\mathrm{TiC}_{0.5} \mathrm{~N}_{0.5}$

Photo. 3 Microstructures of $\mathrm{TiC}_{0.7} \mathrm{No.3}_{0}\left(\mathrm{TiC}_{0.5} \mathrm{No}_{0.5}\right)-30 \mathrm{vol}$ $\% \mathrm{~W}$ alloys vacuum-sintered at $1973 \mathrm{~K}$ for $3.6 \mathrm{ks}$.

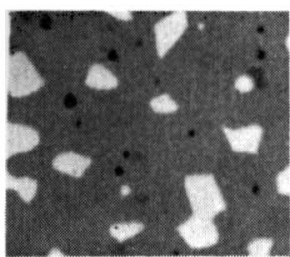

TiC-Mo

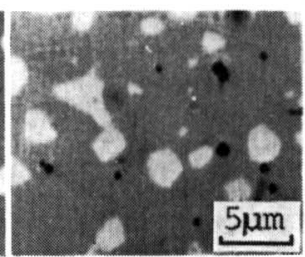

TiC-W
Photo. 4 Microstructures of TiC-30vol\% $\mathrm{Mo}(\mathrm{W})$ alloys vacuum-sintered at $1973 \mathrm{~K}$ for $3.6 \mathrm{ks}$.

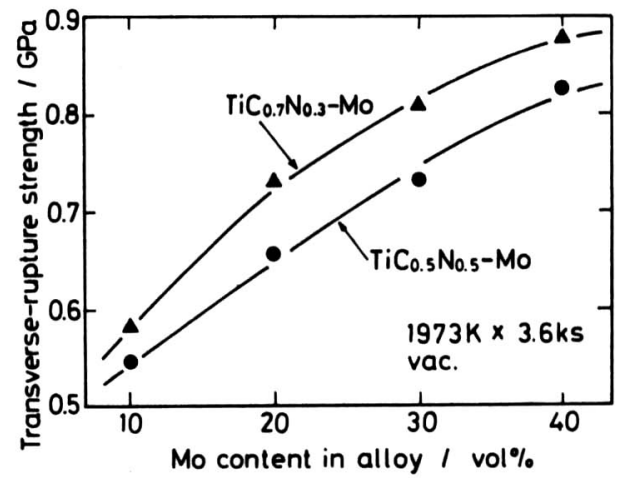

Fig. 3 Effect of Mo content on transverse-rupture strength of $\mathrm{TiC}_{0 .} \mathrm{N}_{0.3}\left(\mathrm{TiC}_{0.5} \mathrm{~N}_{0.5}\right)$-Mo alloys.

種類に応じて, $\mathrm{W}_{2} \mathrm{C}, \mathrm{Mo}_{2} \mathrm{C}$ を生じた.

以上の結果をまとめると, $\mathrm{Ti}(\mathrm{C}, \mathrm{N})$ や $\mathrm{TiC}$ を $\mathrm{Mo}(\mathrm{W})$ で焼結・結合した合金の中では, Ti $(\mathrm{C}, \mathrm{N})$-Mo 合金は炭 窒化物粒度や焼結性を考慮すると，最も優れた，また本 研究では, 緒言で述べているように, Ti(C, N)-Mo 二相 合金を対象としているので，二相合金をうるには $\mathrm{N}_{2}$ 中 焼結よりも真空焼結の方が有利となることも分かった。 よって以下，真空焼結した上記合金に注目し機械的性質 を調べた. Fig. 3 には $\mathrm{TiC}_{0.7} \mathrm{~N}_{0.3}\left(\mathrm{TiC}_{0.5} \mathrm{~N}_{0.5}\right)$-Mo 合金 の抗折力 $\left(\sigma_{m}\right)$ に及ぼす Mo 量の影響を示す. $\sigma_{m}$ は両 合金とも Mo 量の増加と共に上昇するてとが明らかで ある. そして $\mathrm{TiC}_{0.7} \mathrm{~N}_{0.3}-\mathrm{Mo}_{\mathrm{O}}$ 合金の方が全体的に強度 が高い. 破面観察の結果によると, $\mathrm{TiC}_{0.5} \mathrm{~N}_{0.5}-\mathrm{Mo}$ 合金 の方が同一 Mo 量でより粗大なポ了が破壊の起源とな っていたので, Fig. 3 の結果は一忘このためと考元られ た，両合金とむ，破壊の起源となったポア寸法は Mo 量と共に減少した。

Fig. 4 は Fig. 3 に対応する硬さ測定の結果である が，両合金とも硬さは Mo 量と共に低下する。また $\mathrm{TiC}_{0.5} \mathrm{~N}_{0.5}-\mathrm{Mo}$ 合金は他合金よりあわずかに低硬度とな る. 前者は当然の結果であるか，後者は $\mathrm{TiC}_{0.5} \mathrm{~N}_{0.5}-\mathrm{Mo}$ 合金の方が金属 Mo 相量が多かった (Photo. 1) ととに 主因があると思われた。

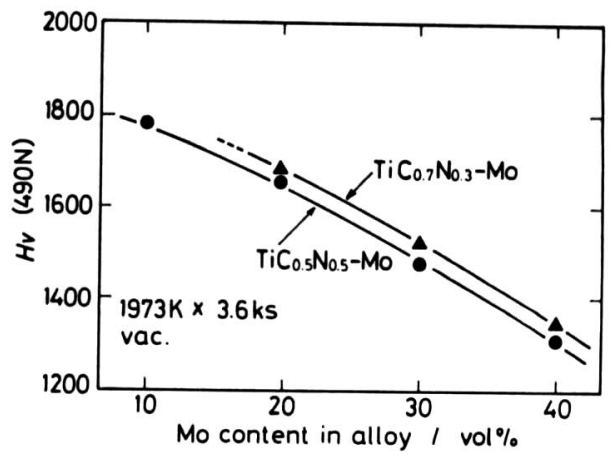

Fig. 4 Effect of Mo content on hardness of $\mathrm{TiC}_{0.7} \mathrm{~N}_{0.3}$ ( $\mathrm{TiC}_{0.5} \mathrm{No.5}_{0}$ )-Mo alloys. 


\section{$\mathrm{V}$ 考 察}

本研究では Ti(C, N), TiC などを $\mathrm{Mo}(\mathrm{W})$ で結合した 烧結合金を，真空中または $\mathrm{N}_{2}$ 中姪結によって調製し， はじわに組織，燒結性などを調べた。その結果， $\mathrm{Ti}(\mathrm{C}$ ， N)-Mo 合金は最も優れ，目的とする二相合金をうるに は真空䡒結が有利であることが分かったので，次に本合 金の室温機械的性椞を調へ，本合金に関する一応の基礎 的知見をうることができた．よってととでは Ti(C,N)Mo 合金に限定し，えられた結果簡単に考察する。

Fig. 5 は Rudy ${ }^{6}$ による Ti-Mo-C 三元系平衡状態図 (1773K 断面図) であるが，てれより TiC と Mo を出 発原料とし, Mo 量をある量以上にすると, $\mathrm{TiC}(\delta)+\mathrm{Mo}$ (B) の二相合金がえられることが分かる。本研究では $\mathrm{TiC}$ の代わりに $\mathrm{Ti}(\mathrm{C}, \mathrm{N})$ を用いているが，相関係の説 明には Fig. 5 が参考になるう. 事実, Photo. 1 をみると Mo が少量の場合は炭窒化物のみの単相組織となり，多 量の場合は（炭窒化物 $+\mathrm{Mo}$ ) の二相組織となっている。 ここで相平衡にあずかる炭窒化物は既述の SS であるこ とば述べるであないことである，ところで炭窒化物粒 度は高N合金ほど娍少した。これは商N合金ほど SSの 愿さが減少するためであるが，その理目については既 報3,7てで述べた通りである，即ち，Moは高温で窒化物を 形成しにくいため, Ti(C, N) 中のN量が多くなるほど Mo がSS 中に固溶しにくくなるのが, その理由と考え られる ${ }^{3,7}$. そうすると高N合金ほど Mo 相量が増加し た現象もよく理解できる。なお，炭空化物は高 Mo 合 金ほど微粒化したが，これはそのような合金ほど焼結初 期にどの Ti(C, N) 粒子にも SS が形成されやすくなり， $\mathrm{Ti}(\mathrm{C}, \mathrm{N})$ 粒子同志の接着が挪えられたためと思われる $\mathrm{Ti}(\mathrm{C}, \mathrm{N})-\mathrm{W}$ 合金では, SS 形成温度が高いために，W量 が多い場合でも，SS 形成前に炭空化物が凝集し，その 結果粗粒組織になったと考えられる ${ }^{32}$.

次に， $\mathrm{N}_{2}$ 中燒結の組織にふれる. $\mathrm{N}_{2}$ 中で焼結する

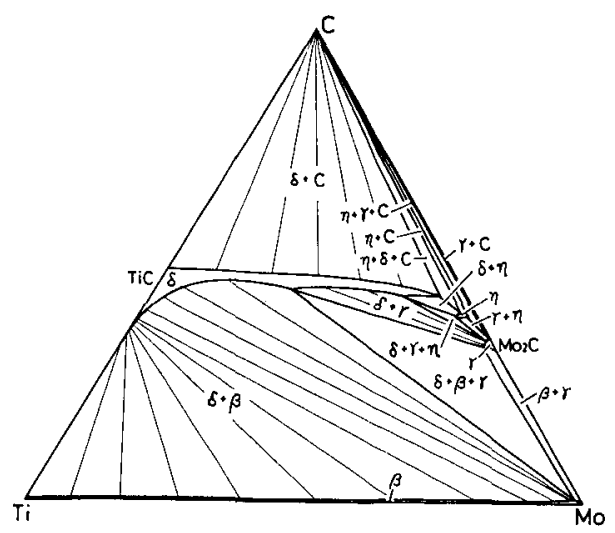

Fig. 5 1773K isothermal section of Ti-Mo-C equilibrium diagram by Rudy ${ }^{6}$.

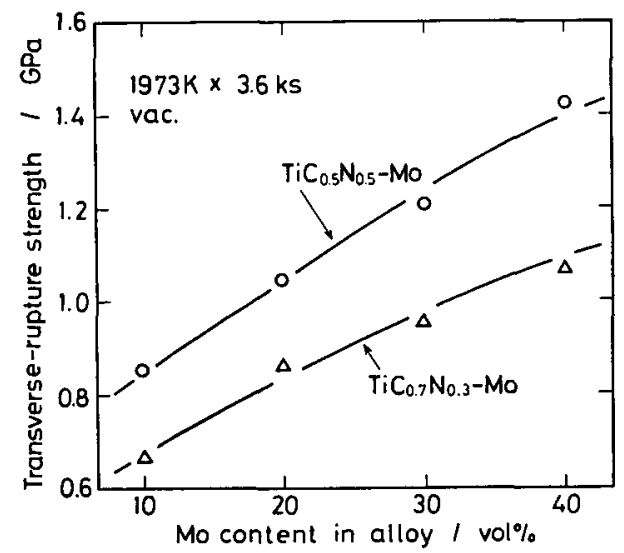

Fig. 6 Transverse-rupture strength of $\mathrm{TiC}_{0.7 \mathrm{No} .3}$ ( $\mathrm{TiCO}_{0.5}$ No.5)-Mo alloys hot-isostatically pressed at $2073 \mathrm{~K}$ Specimens were vacuum-sintered at $1973 \mathrm{~K}$ before HIP.

と，真空焼結の場合は脱窒するのに対し，それが抑えら れ，ある $P_{N_{2}}$ 以上で加窒される (Fig. 2)ので，乙の条 件下では，当然のことながら， Ti(C,N) からCが析出す ることになる．故に高 $\mathrm{Mo}$ 合金を $\mathrm{N}_{2}$ 中で烧結すると， ある $P_{N_{2}}$ 以上で $\mathrm{Mo}_{2} \mathrm{C}$ が生じてむよいと思う. Fig. 5 の状態図をみると，合金中の C 量が増加すると組織は $(\delta+\beta) \rightarrow(\delta+\beta+\gamma) \rightarrow(\delta+\gamma)$ のように変化する（ここで $\delta$, $\beta, \gamma$ はそれぞれ TiC, Mo, $\left.\mathrm{Mo}_{2} \mathrm{C}\right)$ ので, $\mathrm{Mo}_{2} \mathrm{C}$ の発生は 合理的と考えられた．しかし $\mathrm{M}_{2} \mathrm{C}$ を生じれば目的之 する二相合金はえられなくなるので，二相合金をうるに は $\mathrm{TiC}_{0.7} \mathrm{~N}_{0.3}-\mathrm{Mo}$ 合金では $P_{N_{2}} \lesssim 0.1 \mathrm{kPa}$ のような低 $P_{N_{2}}$ が必要となる. $\mathrm{TiC}_{0.5} \mathrm{~N}_{0.5}-\mathrm{Mo}$ 合金では $P_{N_{2}} \leqq 0.5$ 〜1.0kPa 程度ししなければならない。乙のことは, 工 業的な観点に立つと，原料粉林中の $\mathrm{N}$ 量を予め調節して おき，真空焼結によって所定の $\mathrm{N}$ 量の合金をうることの 方が有利であることを示すようである。

したがって，本研究では真空焼結した Ti $(\mathrm{C}, \mathrm{N})-\mathrm{M}$ 合金に注目し，その機械的性質を調べたわけであるが， この結果によると $\sigma_{m}$ は $\mathrm{M}_{0}$ 量によらず $\mathrm{TiC}_{0.7} \mathrm{~N}_{0.3}$ Mo 合金の方が $\mathrm{TiC}_{0.5} \mathrm{~N}_{0.5}$-Mo合金よりも優れた。これ は高 $\mathrm{N}$ 合金ほよ゙脱窒量が多くなるため，脱絰による $\mathrm{N}_{2}$ ガスを娔結体中に包蔵しやすくなり，粗大ポアを生じた ことによるとしてよい ${ }^{8)}$. Fig. 6 には真空烇結後, HIP 処理を施した $\mathrm{TiC}_{0.7} \mathrm{~N}_{0.3}\left(\mathrm{TiC}_{0.5} \mathrm{~N}_{0.5}\right)$-Mo 合金の $\sigma_{m}$ を 示す. 各合金の $\sigma_{m}$ はHIP 後, 焼結状態に比べて全体 的に上泉し，とくに $\mathrm{TiC}_{0.5} \mathrm{~N}_{0.5}-\mathrm{Mo}$ 合金の上畕は著し い。ま HIP 後の強度は両合金とも，焼結状態の場合 亡同様，高 Mo 合金ほど優れるが, $\mathrm{N}$ 量の影響について は焼結状態の場合とは逆に高N合金の方が高強度となる。 この時, 両合金とあ破壊の起源はポアではなく，炭空化 物の凝集体 ${ }^{9)}(5 \sim 20 \mu \mathrm{m} \phi)$ となり，その寸法は Photo. 1 の炭空化物粒度とよく対忘して $\mathrm{TiC}_{0.5} \mathrm{~N}_{0.5}$-Mo 合金の 
方がより小さかった．即ち Fig. 6 で高N合金ほど高強 度となったことが一応理解できる（高N合金ほど Mo 相 量の多いとと考慮). しかし既報采の $\mathrm{Ti}(\mathrm{C}, \mathrm{N})-\mathrm{Mo}_{2} \mathrm{C}-$ $\mathrm{Ni}$ 合金の結果によると，高 $\mathrm{N}$ 合金は炭窒化物之結合相 の界面强度か低下し，本質的には強度低下の傾向にある が, 結果的には微粒化効果が優越して, 低 $\mathrm{N}$ 合金上りも 高強度となった．故にての結果を考慮すると，Fig. 6 K おいて高N合金の方が高強度となったてとについては， 上記要因以外飞微粒化任よる合金の强化す考えられる. 次に强度と Mo 量との関係をみると, 両合金とも Mo 量と共に高強度となり，40\% Mo であ強度低下を示さな かった (Fig. 3，6)．乙机は，普通焼結合金の場合は Mo 量之共に破壊の起源となるポア寸法が減少したとと，ま た一般論としては金属相が増加するほど破壊時の塑性的 仕事量が增加するからとしてよい．なおててで，Mo 量 40\%は多量のようにみえるが，既に述べているようにる の一部はSS 形成に消費されているので，実質結合相量 はN量に依存して約20〜30\%となっていることは述べる まで屯ない。

以上により，Ti(C, N)-Mo 合金の性質のあらましが明 らかになった。即ち $\mathrm{Ti}(\mathrm{C}, \mathrm{N})$ と Mo の混合粉末を約 $1973 \mathrm{~K}$ で真空焼結すると合金中 $\mathrm{N}$ 量，Mo 量にもよる が，極めて微細な二相組織がえられ，30〜40\% Mo 合金 の抗折力と硬さはそれぞれ約 $0.8 \mathrm{GPa}, 1400 H_{V}$ 程度の 值を示すととが分かった．HIP 後の強度は 1 1. $4 \mathrm{GPa}$ と侵れるようになるととも分かった．ここで高温特性は 調べなかったが，乙の程度の室温機械的性質を示せば， 本合金はそれなりに新しい材料として，今後の応用が期 待できるのではないかと思われた。

$$
\mathrm{V} \text { 総 括 }
$$

本研究では, 主として $\mathrm{TiC}_{0.7} \mathrm{~N}_{0.3}\left(\mathrm{TiC}_{0.5} \mathrm{~N}_{0.5}\right)-(5 \sim 40)$ vol\%Mo 合金の組織および 室温機械的性質などを検討 したが，えられた結果はおよそ以下の通りである。

(1) $\mathrm{Ti}(\mathrm{C}, \mathrm{N})-\mathrm{M} \circ$ 合金を真空焟結すると, Mo 量が少 ない場合は炭窒化物単相の組織となり，Mo 量を多くす

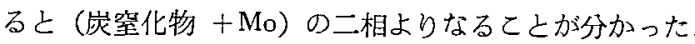
また炭窒化物は高 $\mathrm{N}$, 高 Mo 合金ほど微粒化した，上記 合金をある珐力以上の $\mathrm{N}_{2}$ 中で焼結すると Mo 量が多 量の場合は $\mathrm{Mo}_{2} \mathrm{C}$ を生じるようになる。これは加窒条 件下におかれるためである。

(2) $\mathrm{Ti}(\mathrm{C}, \mathrm{N})-\mathrm{W}$ おょび $\mathrm{TiC}-\mathrm{Mo}(\mathrm{W})$ 合金などは，上 記合金より羊粗粒組織となることが示された。

（3）真空焼結した $\mathrm{Ti}(\mathrm{C}, \mathrm{N})$-Mo 合金の抗折力は低 $\mathrm{N}$, 高 Mo 合金ほど優れ，また硬さは低 $N$, 低 Mo 合金ほ ど上昇した. 30〜 40\% Mo 合金の例を示すと，抗折力， 硬さはそれぞれ約 $0.8 \mathrm{GPa} １ 400 H_{V}$ の值を示すが，焼 結後 HIP 処理を施すと抗折力は 1 1.4GPa に達する ことが分かった。

最後に，本研究の遂行に協力された小谷二郎君（現三 菱金属蚮）に感謝の意を表する。

$$
\text { 文献 }
$$

1)鈴木，林，並木：粉体敊上び溇末冶金，30 (1983)，25.

2) 鉿木，林：粉体叔よび粉末治金， 30 (1983), 243.

3）鈴木，松原：粉体括よび粉末治金, 30 (1983), 257.

4) 鉿木, 松原, 林：日本金属学会誌，46 (1982)，651.

5）鈴木，林，寺田：日本金属学会誌，35 (1971), 936.

6) E. Rudy: Compendium of Phase Diagram Data,(1969) AFML-TR-65-2, Part V.

7）鉿木，林，松原：日本金属学会会報， 22 (1983)， 312.

8）鉿木，松原，齐藤：粉体招上び粉末冶金，31 (1984), 20.

9）鈴木，林，山本：日本金属学会誌，41 (1977), 432. 